\title{
Severe arsenic poisoning: one of the largest man-made catastrophies
}

\author{
K. Golka $\cdot$ J. G. Hengstler $\cdot$ R. Marchan $\cdot$ H. M. Bolt
}

Published online: 13 July 2010

(C) Springer-Verlag 2010

More than 50 million people in Bangladesh are at risk of arsenic-induced disease (Ahmad 2001; Bae et al. 2002). In the 1970s, a nationwide WHO-initiated campaign switched water from ponds and open dug wells to groundwater as a source of drinking water. About 4 million wells have been installed for this purpose. Indeed, this measure reduced waterborne diseases, such as gastrointestinal diseases and infant mortality, as a consequence of drinking bacterialcontaminated water. However, the natural contamination of the groundwater with arsenic because of its contact with arsenic-rich rocks was neglected. Meanwhile, at least 100,000 people have been observed with skin lesions caused by arsenic; however, the real number is probably much higher. Arsenic poisoning is not limited to populations in Bangladesh. In Chile, arsenic in drinking water has been linked to lung and bladder cancer (Orellana 2001). Cases of severe arsenic poisoning as a consequence of fires fueled with high-arsenic coal have also been reported in Guizhou Province in China (Finkelman et al. 1999; Chen et al. 2007, 2009; Lin et al. 2010b). The alarming extent of arseniasis due to drinking water naturally contaminated with arsenic is illustrated by the fact that more than 2 million rural residents in Chinese mainland are at risk (Lin et al. 2010a). Large studies in an area with more than 2,000 arsenic-related skin lesions have shown that the XPD/ ERCC2 $G_{23591} A$ and $A_{35931} C$ polymorphisms modulate the risk for arsenic-induced skin disease (Lin et al. 2010a). Also the GSTP1 $A_{1578} G$ and the GSTM1 polymorphisms

K. Golka $(\bowtie) \cdot$ J. G. Hengstler · R. Marchan · H. M. Bolt

Leibniz-Institut für Arbeitsforschung an der TU Dortmund, Leibniz Research Centre for Working Environment and Human Factors (IfADo), Ardeystrasse 67,

44139 Dortmund, Germany

e-mail: golka@ifado.de might be susceptibility factors for arsenic-related skin lesions (Lin et al. 2007; 2006).

Because of the high relevance and consequences of arsenic poisoning to many of the world's populations, the toxic mechanisms of arsenic have been a central topic in the Archives of Toxicology (Wang et al. 2009; Xi et al. 2009; Juárez-Reyes et al. 2009; Mahmud et al. 2009; Naraharisetti et al. 2008; Beyersmann and Hartwig 2008; Manna et al. 2008; Kobayashi et al. 2008). The editors are happy that Ingrid Druwe and Richard Vaillancourt from The University of Arizona College of Pharmacy, Tucson, have accepted our invitation and reviewed the most up-to-date information available on how arsenate and arsenite influence signal transduction:

- Arsenate enters the cell through transporters that normally transport phosphate into the cell.

- In the cell, arsenate is reduced to arsenite that may undergo a Fenton reaction to produce reactive oxygen species (ROS).

- ROS interacts with Nrf2 resulting in dissociation of Nrf2 from the Keap1-Cul3 complex and its translocation to the nucleus.

- In the nucleus, Nrf2 induces transcription of a battery of genes, including NQO1, GST and HO-1.

- Importantly, arsenite activates the G-protein-coupled receptor in S1P1, which leads to activation of the RasRaf pathway.

- Arsenite inhibits the phosphorylation of Akt, thereby preventing the translocation of the GLUT4 transporter to the cell membrane. This mechanism contributes to arsenic-induced insulin resistance.

These examples illustrate that the current review by Druwe and Vaillancourt (this issue) is a "must-read" for anyone interested in the molecular mode of action of arsenate and arsenite. 


\section{References}

Ahmad K (2001) Report highlights widespread arsenic contamination in Bangladesh. Lancet 358:133

Bae M, Watanabe C, Inaoka T, Sekiyama M, Sudo N, Bokul MH, Ohtsuka R (2002) Arsenic in cooked rice in Bangladesh. Lancet 360:1839-1840

Beyersmann D, Hartwig A (2008) Carcinogenic metal compounds: recent insight into molecular and cellular mechanisms. Arch Toxicol 82:493-512

Chen JG, Chen YG, Zhou YS, Lin GF, Li XJ, Jia CG, Guo WC, Du H, Lu HC, Meng H, Zhang XJ, Golka K, Shen JH (2007) A followup study of mortality among the arseniasis patients exposed to indoor combustion of high arsenic coal in Southwest Guizhou Autonomous Prefecture, China. Int Arch Occup Environ Health 81:9-17

Chen JG, Lin GF, Chen YG, Jia CG, Zhou YS, Meng H, Guo WC, Golka K, Liu KJ, Shen JH (2009) Arseniasis prevalence and mortality in a multiethnic, endemic township in Guizhou, China. Int Arch Occup Environ Health 82:499-508

Finkelman RB, Belkin HE, Zheng B (1999) Health impacts of domestic coal use in China. Proc Natl Acad Sci USA 96:3427-3431

Juárez-Reyes A, Jiménez-Capdeville ME, Delgado JM, Ortiz-Pérez D (2009) Time course of arsenic species in the brain and liver of mice after oral administration of arsenate. Arch Toxicol 83:557563

Kobayashi Y, Negishi T, Mizumura A, Watanabe T, Hirano S (2008) Distribution and excretion of arsenic in cynomolgus monkey following repeated administration of diphenylarsinic acid. Arch Toxicol 82:553-561

Lin GF, Du H, Chen JG, Lu HC, Guo WC, Meng H, Zhang TB, Zhang XJ, Lu DR, Golka K, Shen JH (2006) Arsenic-related skin lesions and glutathione S-transferase P1 A1578G (Ile105Val) polymor- phism in two ethnic clans exposed to indoor combustion of high arsenic coal in one village. Pharmacogenet Genomics 16:863-871

Lin GF, Du H, Chen JG, Lu HC, Kai JX, Zhou YS, Guo WC, Zhang XJ, Lu DR, Golka K, Shen JH (2007) Glutathione S-transferases $\mathrm{M} 1$ and T1 polymorphisms and arsenic content in hair and urine in two ethnic clans exposed to indoor combustion of high arsenic coal in Southwest Guizhou, China. Arch Toxicol 81:545-551

Lin GF, Du H, Chen JG, Lu HC, Guo WC, Golka K, Shen JH (2010a) Association of XPD/ERCC2 G23591A and A35931C polymorphisms with skin lesion prevalence in a multiethnic, arseniasishyperendemic village exposed to indoor combustion of high arsenic coal. Arch Toxicol 84:17-24

Lin GF, Meng H, Du H, Lu HC, Zhou YS, Chen JG, Golka K, Lu JC, Shen JH (2010b) Factors impacting on the excess arseniasis prevalence due to indoor combustion of high arsenic coal in a hyperendemic village. Int Arch Occup Environ Health 83:433-440

Mahmud H, Föller M, Lang F (2009) Arsenic-induced suicidal erythrocyte death. Arch Toxicol 83:107-113

Manna P, Sinha M, Sil PC (2008) Arsenic-induced oxidative myocardial injury: protective role of arjunolic acid. Arch Toxicol 82:137-149

Naraharisetti SB, Aggarwal M, Sarkar SN, Malik JK (2008) Concurrent subacute exposure to arsenic through drinking water and malathion via diet in male rats: effects on hepatic drug-metabolizing enzymes. Arch Toxicol 82:543-551

Orellana C (2001) Arsenic in drinking water linked to lung and bladder cancer. Lancet Oncol 2:194

Wang Y, Xu Y, Wang H, Xue P, Li X, Li B, Zheng Q, Sun G (2009) Arsenic induces mitochondria-dependent apoptosis by reactive oxygen species generation rather than glutathione depletion in Chang human hepatocytes. Arch Toxicol 83:899-908

Xi S, Sun W, Wang F, Jin Y, Sun G (2009) Transplacental and early life exposure to inorganic arsenic affected development and behavior in offspring rats. Arch Toxicol 83:549-556 